\title{
Article \\ New Advances in the Phenolic Composition of Tiger Nut (Cyperus esculentus L.) By-Products
}

\author{
María del Carmen Razola-Díaz ${ }^{1,2}{ }^{\mathbb{D}}$, Ana María Gómez-Caravaca ${ }^{2,3}$, Eduardo J. Guerra-Hernández ${ }^{1}{ }^{\circledR}$, \\ Belén Garcia-Villanova ${ }^{1}$ (D) and Vito Verardo ${ }^{1,2, *(1)}$ \\ 1 Department of Nutrition and Food Science, Campus of Cartuja, University of Granada, 18071 Granada, Spain; \\ carmenrazola@ugr.es (M.d.C.R.-D.); ejguerra@ugr.es (E.J.G.-H.); belenv@ugr.es (B.G.-V.) \\ 2 Institute of Nutrition and Food Technology 'José Mataix', Biomedical Research Centre, University of Granada, \\ Avd. Conocimiento s/n, 18100 Granada, Spain; anagomez@ugr.es \\ 3 Department of Analytical Chemistry, Faculty of Sciences, University of Granada, Avd. Fuentenueva s/n \\ 18071 Granada, Spain \\ * Correspondence: vitoverardo@ugr.es
}

check for updates

Citation: Razola-Díaz, M.d.C.;

Gómez-Caravaca, A.M.;

Guerra-Hernández, E.J.;

Garcia-Villanova, B.; Verardo, V. New

Advances in the Phenolic

Composition of Tiger Nut (Cyperus

esculentus L.) By-Products. Foods 2022,

11, 343. https://doi.org/10.3390/

foods 11030343

Academic Editor: Victor Rodov

Received: 4 December 2021

Accepted: 20 January 2022

Published: 25 January 2022

Publisher's Note: MDPI stays neutral with regard to jurisdictional claims in published maps and institutional affiliations.

Copyright: (C) 2022 by the authors. Licensee MDPI, Basel, Switzerland. This article is an open access article distributed under the terms and conditions of the Creative Commons Attribution (CC BY) license (https:// creativecommons.org/licenses/by/ $4.0 /)$.

\begin{abstract}
Horchata" is a well-known Spanish beverage obtained from pressing tiger nuts. Its by-product is a potential source of sugar and fiber but also contains polyphenols; thus, it could be used as a new ingredient in the food industry. The aim of this work is to determine the phenolic compounds and compare the phenolic profile of two tiger nut by-products. A Box-Behnken design has been carried out to optimize the extraction of phenolic compounds from tiger nut by-products by ultrasound technology. The independent factors were time ( $\mathrm{min})$, ethanol/water $(\% v / v)$, and solvent/sample ratio $(v / w)$. The model was validated and confirmed by ANOVA. A Protected Designation of Origin (PDO) of Valencia and a non-Protected Designation of Origin (n-PDO) tiger nut by-products were extracted under the optimal conditions and were characterized by HPLC-DADESI-TOF-MS (High Performance Liquid Chropatography coupled to a photodiode array time-offlight mass detector). Moreover, their antioxidant activities measured by three different methods (DPPH (2,2-diphenyl-1-picrylhydrazyl), ABTS (2,2'-Azinobis [3-ethylbenzothiazoline-6-sulfonic acid]diammonium salt) and FRAP (ferric reducing antioxidant power)) were compared. A total of 45 polar compounds were identified, and the phenolic ones were quantified, some of them for the first time. PDO tiger nut by-product has been demonstrated to be richer in phenolic acids and other polyphenols and has higher antioxidant activity; meanwhile, n-PDO tiger nut by-product is richer in phenol precursors.
\end{abstract}

Keywords: ultrasound-assisted extraction; phenolic compounds; antioxidant activity; chufa; HPLC-ESI-TOF-MS

\section{Introduction}

Tiger nut (Cyperus esculentus L.) is a tuber mainly used to obtain a tiger nut beverage with a milky appearance, called "horchata". It is typically from Spain, where the horchata production industry supposes $€ 60$ million per year. The by-products generated from this industry are up to $60 \%$ of the tiger nut used, which equals 1.8 million $\mathrm{kg}$ per year. Tiger nut by-products are mainly used for animal feed or as organic matter for combustion [1], as a carbon source for the growth of probiotic bacteria [2], or as a sugar source for microalgae [3]. Besides, there are several studies that have evaluated the potential of this by-product as a source of fiber to enrich meat products such as pork [4], beef [5] burgers, and pork sausages [6], to enhance cooking performance, moisture and fat retention. However, there are only a few studies concerning the potential use of this by-product for food and nutraceutical industries. Some studies have evaluated enzyme pretreatments combined with high pressure [7] or different mixtures of solvents at different temperatures [8] to extract 
phenolic compounds from tiger nut by-product. Nevertheless, they only used spectrophotometric methods to quantify total phenolic compounds, but individual components were not quantified nor chemically characterized. More recent studies have characterized the phenolic profile of the tiger nut by-product extracted by conventional extraction [9] or of the tiger nut by-product oil by supercritical fluid extraction with $\mathrm{CO}_{2}$ [10]. Clemente-Villalba et al. (2021) [11] have recently published a comparison of the sensory profile, volatile composition, and consumer's acceptance of PDO and n-PDO tiger nut milks. Razola Díaz et al. (2020) [3] compared the chemical composition and sugar content in PDO and n-PDO tiger nut by-products. Thus, the objective of the present study is to compare, for the first time, the phenolic profiles of two tiger nut by-products from different origins (PDO and $\mathrm{n}-\mathrm{PDO}$ ) that were obtained during production at an industrial scale. The extraction of phenolic compounds was optimized using ultrasound technology with a Box-Behnken design. All the polar compounds were tentatively identified by HPLC-ESI-TOF-MS, and the phenolics were quantified. The antioxidant activity of both by-products was measured by three different methods (DPPH, ABTS, and FRAP).

\section{Materials and Methods}

\subsection{Chemicals and Samples}

HPLC (High Performance Liquid Chromatography)-grade water and other reagents and solvents were purchased from Merck KGaA (Darmstadt, Germany).

Tiger nut by-product samples were provided by Puleva company located in Granada, Spain, in May 2019. Two types of samples were collected, one from Protected Designation of Origin (PDO) of Valencia and another one without appellation of origin (non-Protected Designation of Origin (n-PDO)) from Ivory Coast. The PDO by-product was obtained after three successive pressings of the tiger nut, while the n-PDO by-product was obtained after only two presses due to its original composition and the final target product of the company as the non-PDO tiger nut was richer in fat. The samples were dried in a ventilated oven at $40{ }^{\circ} \mathrm{C}$ until obtaining $5.57 \pm 0.29$ and $5.46 \pm 0.67 \%$ of humidity in the PDO and n-PDO tiger nut by-product, respectively, and milled and sieved to $100 \mu \mathrm{m}$; after that, they were frozen at $-18{ }^{\circ} \mathrm{C}$ until the analyses.

\subsection{Experimental Design}

A Box-Behnken design composed of 15 experiments in three levels $(-1,0,1)$ was established to optimize the extraction of phenolic compounds from tiger nut by-products. All the parameters of the model were established according to the previous experience of the group and previous trials. The independent variables were time (5, 45 and $85 \mathrm{~min})$, ratio ethanol/water (0,50 and 100\% v/v), and ratio solvent/sample (20, 40 and $100 v / w)$, and the response was the total phenolic content measured using the Folin-Ciocalteu method. The model was fitted to a second-order polynomial equation, and its adjustment was evaluated and confirmed by ANOVA. To select the optimal conditions, response surface methodology (RSM) was used. All the data was processed using STATISTICA 7.0 (2002, StatSoft, Tulsa, OK, USA).

\subsection{Ultrasound Bath Extraction}

Briefly, $0.125 \mathrm{~g}$ of tiger nut by-product powder was dissolved in a $10 \mathrm{~mL}$ solution of ethanol/water 40/60, v/v. The mixture was placed in an ultrasonic bath for $50 \mathrm{~min}$, and then it was centrifuged for $10 \mathrm{~min}$ at $9000 \mathrm{rpm}$. The supernatant was collected, evaporated, and reconstituted in $1 \mathrm{~mL}$ of methanol/water $(50: 50, v / v)$. The final extracts were filtered with regenerated cellulose filters $0.2 \mu \mathrm{m}$ (Millipore, Bedford, MA, USA) and stored at $-18^{\circ} \mathrm{C}$ until the analyses.

\subsection{Determination of Total Phenolic Content (TPC)}

Folin-Ciocalteu spectrophotometric method was used to determine the TPC in tiger nut by-product [12]. Thus, $100 \mu \mathrm{L}$ of the extract was added to $500 \mu \mathrm{L}$ of the Folin-Ciocalteu 
reagents and $6 \mathrm{~mL}$ of bi-distilled water. The flask was agitated for a minute. After that, $2 \mathrm{~mL}$ of $15 \%(w / v) \mathrm{Na}_{2} \mathrm{CO}_{3}$ and made up to $10 \mathrm{~mL}$ with bi-distilled water. The flasks were kept in darkness. After $2 \mathrm{~h}$, the measures were carried out at $750 \mathrm{~nm}$ and $25{ }^{\circ} \mathrm{C}$ with a UV-visible spectrophotometer (Spectrophotometer 300 Array, UV-Vis, single beam, Shimadzu, Duisburg, Germany). The calibration curve was developed with Gallic acid from 1 to $100 \mathrm{ppm}$, and the obtained equation was $\mathrm{y}=0.0012 \mathrm{x}+0.0227\left(\mathrm{R}^{2}=0.9995\right)$. Results are expressed as $\mu \mathrm{g}$ gallic acid equivalents (GAE)/g dry weight (d.w.).

\subsection{Determination of Polar Compounds by HPLC-ESI-QTOF-MS}

The phenolic profile characterization and quantification of the two tiger nut byproducts extracted by the optimal conditions were performed according to a previously described method [13]. The analyses were carried out in duplicate on an ACQUITY Ultra Performance LC system (Waters Corporation, Milford, MA, USA) coupled to an electrospray ionization (ESI) source operating in the negative mode and a time-of-flight (TOF) mass detector (Waters Corporation, Milford, MA, USA). The compounds of interest were separated on an ACQUITY UPLC BEH Shield RP18 column $(1.7 \mu \mathrm{m}, 2.1 \mathrm{~mm} \times 100 \mathrm{~mm}$; Waters Corporation, Milford, MA, USA) at $40{ }^{\circ} \mathrm{C}$ using a gradient previously stated by Verni et al. [13] using water containing $1 \%$ acetic acid as mobile phase A and acetonitrile as mobile phase $\mathrm{B}$. The gradient was: from 0 to $2.3 \mathrm{~min}, 1 \% \mathrm{~B} ; 4.4 \mathrm{~min}, 7 \% \mathrm{~B} ; 8.1 \mathrm{~min}, 14 \% \mathrm{~B}$; $12.2 \mathrm{~min}, 24 \% \mathrm{~B} ; 16 \mathrm{~min}, 40 \% \mathrm{~B} ; 18.3 \mathrm{~min}, 100 \% \mathrm{~B}, 21 \mathrm{~min}, 100 \% \mathrm{~B} ; 22.4 \mathrm{~min}, 1 \% \mathrm{~B} ; 25 \mathrm{~min}$, $1 \% \mathrm{~B}$. Flow rate was established to $0.6 \mathrm{~mL} / \mathrm{min}$. The volume injection was $2 \mu \mathrm{L}$.

Finally, external calibration curves were prepared for the quantification of phenolic compounds: vanillic acid $\left(y=99.369 x+40.864, \mathrm{R}^{2}=0.9995\right)$, ferulic acid $(\mathrm{y}=173.03 \mathrm{x}+$ $\left.64.326, R^{2}=0.9958\right)$, rutin $\left(y=1137.8 x+74.815, R^{2}=0.9943\right)$, quercetin $(y=1272.5 x+84.49$, $\left.R^{2}=0.9938\right)$, and catechin $\left(y=317.69 x+105.65, R^{2}=0.9955\right)$. The data were elaborated using MassLynx 4.1 software (Waters Corporation, Milford, MA, USA).

\subsection{Antioxidant Assays in Tiger Nut By-Products}

The antioxidant capacity in the two tiger nut by-products has been evaluated in the extract obtained by the optimal ultrasound bath conditions using three different methods

The ABTS method was carried out according to Re et al. (1999) [14]. The monocation $\mathrm{ABTS}^{\bullet+}$ is generated by oxidation of the ABTS with potassium persulfate in the dark at room temperature for $12-24 \mathrm{~h}$. For each extract, $1 \mathrm{~mL}$ of this ABTS solution was added to $0.01 \mathrm{~mL}$ of the extract and the detriment of absorbance during $30 \mathrm{~min}$ at $734 \mathrm{~nm}$ was measured.

The DPPH radical scavenging activity was assayed with a method proposed by several authors [15,16]. In total, $100 \mu \mathrm{L}$ of each extract was added to $2.9 \mathrm{~mL}$ of DPPH, and after rapid stirring, the bleaching power of the extract was observed in a time interval from 0 to $30 \mathrm{~min}$ at $517 \mathrm{~nm}$.

The FRAP assay was carried out following the procedure developed by Pulido et al. (2000) [17]. It is based on the reduction of $\mathrm{Fe}^{3+}$ to $\mathrm{Fe}^{2+}$ by the antioxidant substances. A total of $30 \mu \mathrm{L}$ of each extract was added to $90 \mu \mathrm{L}$ of distilled water and $900 \mu \mathrm{L}$ of the FRAP reagent. It was kept for $30 \mathrm{~min}$ at $37^{\circ} \mathrm{C}$ and measured in the spectrophotometer at $595 \mathrm{~nm}$.

Standard curves of Trolox equivalents (TE) $(1,5,10,20,50,80,100,150,200 \mathrm{ppm})$ were elaborated for each assay and the equations obtained were $y=0.0009 x+0.0258\left(R^{2}=0.9971\right)$, $y=0.0026 x+0.0374\left(R^{2}=0.9963\right)$, and $y=0.0039 x+0.0915\left(R^{2}=0.9972\right)$, for the ABTS, $\mathrm{DPPH}$, and FRAP assays, respectively. Results are expressed as $\mathrm{mg} \mathrm{TE} / \mathrm{g}$ d.w.

\section{Results and Discussion}

\subsection{Fitting the Model}

The extraction step is the most important to reach the highest amount of the target compounds, in this case, phenolic compounds. A Box-Behnken design coupled to RSM was used to find the optimal conditions of time $\left(X_{1}\right)$, ethanol/water ratio $\left(X_{2}\right)$, and solvent/sample ratio $\left(X_{3}\right)$ to extract phenolic compounds from the tiger nut by-product using ultrasound bath technology. The experimental values of TPC obtained for each run are shown in Table 1. 
The lowest recovery ( $42.80 \pm 1.08 \mu \mathrm{g} \mathrm{GAE} / \mathrm{g}$ d.w.) was at $45 \mathrm{~min}$, with the ethanol/water $100 \%$ and ratio solvent/sample $20 \mathrm{v} / \mathrm{w}$, and the highest (383.11 $\pm 1.76 \mu \mathrm{g} \mathrm{GAE} / \mathrm{g} \mathrm{d} . \mathrm{w}$.$) at$ $85 \mathrm{~min}$, was ethanol/water 50\% and ratio solvent/sample $100 \mathrm{v} / \mathrm{w}$. This by-product has a low relation weight/volume $(<1)$; therefore, those experiments carried out with the lower value of ratio solvent/sample led to the lowest results due to the saturation of the solvent and consequently the reduced contact surface between sample and solvent. Similar results were found when the tendency using ethanol was 100\%; therefore, it demonstrates that some water is needed as surfactant for the extraction of phenolic compounds to satisfactorily take place.

Table 1. Box-Behnken design with natural and coded values (parenthesis) of the conditions of extraction and the experimental results obtained for total phenolic content (TPC) expressed with the average and the standard deviation.

\begin{tabular}{|c|c|c|c|c|}
\hline \multirow{2}{*}{ Run } & \multicolumn{3}{|c|}{ Independent Factors } & \multirow{2}{*}{$\begin{array}{c}\text { Response } \\
\text { TPC ( } \mu \text { g GAE/g d.w.) }\end{array}$} \\
\hline & $X_{1}$ & $X_{2}$ & $X_{3}$ & \\
\hline 1 & $5(-1)$ & $0(-1)$ & $40(0)$ & $124.02 \pm 1.60$ \\
\hline 2 & $85(1)$ & $0(-1)$ & $40(0)$ & $142.00 \pm 1.46$ \\
\hline 3 & $5(-1)$ & $100(1)$ & $40(0)$ & $57.95 \pm 0.91$ \\
\hline 4 & $85(1)$ & $100(1)$ & $40(0)$ & $93.64 \pm 0.40$ \\
\hline 5 & $5(-1)$ & $50(0)$ & $20(-1)$ & $135.34 \pm 1.44$ \\
\hline 6 & $85(1)$ & $50(0)$ & $20(-1)$ & $100.73 \pm 1.74$ \\
\hline 7 & $5(-1)$ & $50(0)$ & $100(1)$ & $278.72 \pm 1.67$ \\
\hline 8 & $85(1)$ & $50(0)$ & $100(1)$ & $383.11 \pm 1.76$ \\
\hline 9 & $45(0)$ & $0(-1)$ & $20(-1)$ & $77.80 \pm 1.11$ \\
\hline 10 & $45(0)$ & $100(1)$ & $20(-1)$ & $42.80 \pm 1.08$ \\
\hline 11 & $45(0)$ & $0(-1)$ & $100(1)$ & $281.54 \pm 1.48$ \\
\hline 12 & $45(0)$ & $100(1)$ & $100(1)$ & $221.53 \pm 1.12$ \\
\hline 13 & $45(0)$ & $50(0)$ & $40(0)$ & $305.47 \pm 1.06$ \\
\hline 14 & $45(0)$ & $50(0)$ & $40(0)$ & $291.97 \pm 1.93$ \\
\hline 15 & $45(0)$ & $50(0)$ & $40(0)$ & $298.69 \pm 1.75$ \\
\hline
\end{tabular}

$\mathrm{X}_{1-3}$ : Time (min), ethanol/water $(\% v / v)$, and solvent/sample ratio $(v / w)$.

The experimental data were adjusted to a second-order polynomial equation, and all the estimated regression effects are shown in Table 2 . The model was analyzed with a significance level of $p<0.05$, and all the lineal terms $\left(\beta_{1}, \beta_{2}\right.$, and $\left.\beta_{3}\right)$, all the quadratic terms $\left(\beta_{11}, \beta_{22}\right.$ and $\left.\beta_{33}\right)$, and the crossed values between time $\left(X_{1}\right)$ and ratio solvent/sample $\left(X_{3}\right)$, had significance, but the rest of the terms were discarded. Therefore, the model was recalculated, and the ANOVA test was performed. As shown in Table 2 the model revealed a high correlation coefficient $\left(\mathrm{R}^{2}=0.9891\right)$, a significant regression model $(p<0.05)$, and a non-significant lack of fit $(p>0.05)$. According to Bezerra et al. [18], the adequacy of the model was confirmed.

Optimal conditions were selected using RSM concerning the three-dimensional graphs presented in Figure 1. A compromise has been made between the independent factors to establish them at the minimal possible values. The optimal conditions chosen were: $50 \mathrm{~min}, 40 \%$ ethanol/water, and ratio solvent/sample $80 \mathrm{v} / \mathrm{w}$ that gave a predicted value of $403.61 \pm 49.54 \mu \mathrm{g}$ GAE/g d.w. The coefficient of variation between the obtained $(400.43 \pm 4.63)$ and predicted values was lower than $1 \%$, so the model was validated.

The optimal result obtained was better than the one reported by Roselló-Soto et al. [8] that used conventional extraction with a similar solvent (ethanol 25\%) but with differences in terms of time $(3 \mathrm{~h})$ and temperature $\left(60^{\circ} \mathrm{C}\right)$. Therefore, ultrasound technology has been demonstrated to be a non-thermal and lower time-consuming technique that allows the satisfactorily recovery of phenolic compounds from tiger nut by-products. However, the authors reported slightly higher results using $50 \%$ ethanol, $35^{\circ} \mathrm{C}$, and $\mathrm{pH} 2.5$ for $3 \mathrm{~h}$ [9]. In our case, the $\mathrm{pH}$ has not been changed in order to avoid the hydrolysis of bound compounds. 
Table 2. Estimated regression effects of the fitted second-order polynomial equation and ANOVA of the fitted model.

\begin{tabular}{|c|c|c|c|c|}
\hline \multirow{2}{*}{ Regression Coefficients } & \multicolumn{4}{|c|}{ Response } \\
\hline & Effect & Standard Error & $t$-Value & $p$-Value \\
\hline$\beta_{0} *$ & 178.4055 & 1.9924 & 89.5448 & 0.0001 \\
\hline \multicolumn{5}{|l|}{ Lineal } \\
\hline$\beta_{1} *$ & 46.8713 & 5.0403 & 9.2993 & 0.0114 \\
\hline$\beta_{2} *$ & -52.3614 & 4.7817 & -10.9505 & 0.0082 \\
\hline$\beta_{3} *$ & 201.9806 & 4.7817 & 42.2407 & 0.0006 \\
\hline \multicolumn{5}{|l|}{ Quadratic } \\
\hline$\beta_{11}^{*}$ & 62.9065 & 3.5192 & 17.8752 & 0.0031 \\
\hline$\beta_{22} *$ & 131.3867 & 3.5192 & 37.3342 & 0.0007 \\
\hline$\beta_{33}$ * & 61.8885 & 3.7167 & 16.6515 & 0.0036 \\
\hline \multicolumn{5}{|l|}{ Crossed } \\
\hline$\beta_{12}$ & 8.8587 & 6.7623 & 1.3100 & 0.3204 \\
\hline$\beta_{13}$ * & 63.7294 & 6.3755 & 9.9959 & 0.0099 \\
\hline$\beta_{23}$ & -12.5084 & 6.7623 & -1.8497 & 0.2056 \\
\hline$R^{2}$ & \multicolumn{4}{|c|}{0.9891} \\
\hline$p$ model & \multicolumn{4}{|c|}{0.0000} \\
\hline$p$ lack of fit & \multicolumn{4}{|c|}{0.2304} \\
\hline
\end{tabular}

*: Significant at 0.05 .
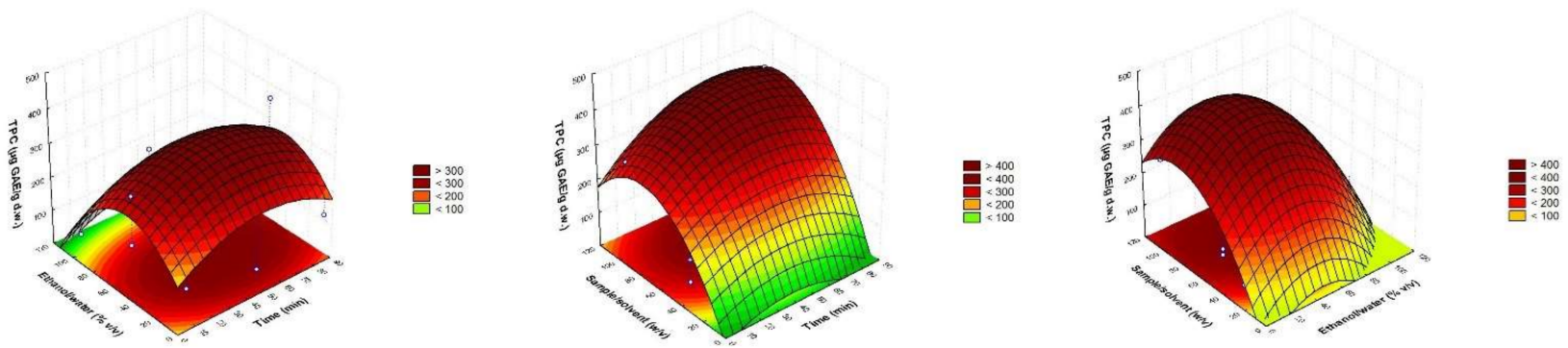

Figure 1. Response surface plots showing combined effects of process variables.

\subsection{Identification of Polar Compounds by HPLC-ESI-TOF-MS}

The samples of PDO and n-PDO tiger nut by-products were characterized by HPLCMS, and 44 compounds were identified, 18 were phenolic compounds and 26 other polar compounds were identified as hydroxyl fatty acids. To our knowledge, a total of 27 polar compounds were identified for the first time in tiger nut by-products.

All the identified compounds are described in Table 3 with their retention time, molecular formula, experimental and calculated $\mathrm{m} / \mathrm{z}$ fragments, and score and error (ppm). To ensure mass accuracy, the tolerances chosen had a score higher than $90 \%$ and an error lower than 5 ppm (part per million) between the experimental and calculated $m / z$. To identify the compounds, the generated molecular formula and some in source fragments were checked and studied also comparing with different databases such as PubChem, Phenol-Explorer, and the literature.

Five phenolic acids were identified at times 1.34, 2.57, 3.88, 5.51, and $5.73 \mathrm{~min}$ (peaks $4,6,7,9$, and 19). They were named $p$-hydroxybenzoic acid, vanillic acid, ethyl vanillin, ferulic acid, and $p$-coumaric acid, respectively. In addition, peaks 2, 8, 15, and 21 were assigned to scopoletin (a coumarin), 4-vinylphenol (a hydroxy styrene), sinensetin (a methylated flavone), and cyanidin (an anthocyanidin), with $m / z$ 191, 119, 371, and 286, respectively. These compounds are in agreement with Roselló-Soto et al. $(2019)[9,10]$ who previously described them in tiger nut by-product. As they described some vanillin and p-coumaric acid derivates, the compounds found at 9.47 and 12.67 min (peaks 13 and 17) were named dehydrovanillin and $p$-coumaric acid ethyl ester, respectively. Overall vanillic and $p$-coumaric acid derivates described here were attributed to have good bioavailability and bio-accessibility and to reduce the risk of developing several disorders such as cancer and cardiovascular diseases [19]. 
Table 3. Polar compounds tentatively identified by HPLC-ESI-TOF-MS.

\begin{tabular}{|c|c|c|c|c|c|c|c|c|}
\hline No. & Compound & $\begin{array}{c}\text { Retention Time } \\
\text { (min) }\end{array}$ & $\begin{array}{l}\text { Molecular } \\
\text { Formula }\end{array}$ & $\begin{array}{c}m / z \\
\text { Experimental }\end{array}$ & $\begin{array}{c}m / z \\
\text { Calculated }\end{array}$ & Fragments & $\begin{array}{l}\text { Score } \\
(\%)\end{array}$ & $\begin{array}{l}\text { Error } \\
(\mathrm{ppm})\end{array}$ \\
\hline 1 & 2-O-Galloyl-1,4-galactarolactone & 0.274 & $\mathrm{C}_{13} \mathrm{H}_{12} \mathrm{O}_{11}$ & 343.0308 & 343.0301 & 201.0249 & 90.7 & 2.0 \\
\hline 2 & Scopoletin & 0.520 & $\mathrm{C}_{10} \mathrm{H}_{8} \mathrm{O}_{4}$ & 191.1686 & 191.1680 & $111.0071 ; 174.0401 ; 160.8401$ & 100 & -3.1 \\
\hline 3 & Imbricantonol & 1.155 & $\mathrm{C}_{26} \mathrm{H}_{20} \mathrm{O}_{7}$ & 443.1111 & 443.1131 & $214.9512 ; 229.0186 ; 570.0947$ & 93.9 & -4.5 \\
\hline 4 & $p$-hydroxybenzoic acid & 1.341 & $\mathrm{C}_{7} \mathrm{H}_{6} \mathrm{O}_{3}$ & 137.0234 & 137.0239 & - & 100 & -3.6 \\
\hline 5 & L-leucic acid & 1.916 & $\mathrm{C}_{6} \mathrm{H}_{12} \mathrm{O}_{3}$ & 131.0702 & 131.0708 & 85.0646 & 100 & -4.6 \\
\hline 6 & Vanillic acid & 2.570 & $\mathrm{C}_{8} \mathrm{H}_{8} \mathrm{O}_{4}$ & 167.0338 & 167.0344 & - & 100 & -3.6 \\
\hline 7 & Ethyl vanillin & 3.877 & $\mathrm{C}_{9} \mathrm{H}_{10} \mathrm{O}_{3}$ & 165.0556 & 165.0552 & $151.8809 ; 136.9292$ & 100 & 2.4 \\
\hline 8 & 4-vinylphenol & 4.643 & $\mathrm{C}_{8} \mathrm{H}_{8} \mathrm{O}$ & 119.0492 & 119.0497 & - & 100 & -4.2 \\
\hline 9 & Ferulic acid & 5.515 & $\mathrm{C}_{10} \mathrm{H}_{10} \mathrm{O}_{4}$ & 193.0504 & 193.0501 & $134.0359 ; 166.9101$ & 100 & 1.6 \\
\hline 10 & $p$-coumaric acid & 5.734 & $\mathrm{C}_{9} \mathrm{H}_{8} \mathrm{O}_{3}$ & 163.0403 & 163.0395 & $119.0499 ; 117.0318 ; 149.0263$ & 100 & 4.9 \\
\hline 11 & 3-Hydroxyphloretin 2'-O-glucoside (aspalathin) & 7.505 & $\mathrm{C}_{21} \mathrm{H}_{24} \mathrm{O}_{11}$ & 451.3276 & 451.3271 & $\begin{array}{c}225.1289 ; 337.1716 ; 433.2887 ; 291.9893 ; \\
189.9602 ;\end{array}$ & 100 & 1.1 \\
\hline 12 & $\begin{array}{l}\text { Kaempferol 3,7-diglucoside, } \\
\text { sophoraflavonoloside or } \\
\text { luteolin-7,3'-di-O-glucoside }\end{array}$ & 8.246 & $\mathrm{C}_{27} \mathrm{H}_{30} \mathrm{O}_{16}$ & 609.1453 & 609.1456 & $\begin{array}{c}297.0602 ; 153.0205 ; 507.1086 ; 285.0299 ; \\
447.0884\end{array}$ & 93.4 & -0.5 \\
\hline 13 & Dehydrodivanillin & 9.467 & $\mathrm{C}_{16} \mathrm{H}_{14} \mathrm{O}_{6}$ & 301.0698 & 301.0712 & $286.0476 ; 166.9093 ; 215.0308 ; 239.0385$ & 99.9 & -4.7 \\
\hline 14 & Veronicafolin 3-glucosyl-(1->3)-galactoside & 9.652 & $\mathrm{C}_{30} \mathrm{H}_{36} \mathrm{O}_{18}$ & 683.1799 & 683.1823 & 721.1418; 593.1249; 563.1607 & 94.7 & -3.5 \\
\hline 15 & Sinensetin & 10.368 & $\mathrm{C}_{20} \mathrm{H}_{20} \mathrm{O}_{7}$ & 371.1117 & 371.1131 & $\begin{array}{c}175.0426 ; 193.0490 ; 145.0287 ; 161.0240 ; \\
161.9289\end{array}$ & 97.6 & -3.8 \\
\hline 16 & Sinapyl alcohol & 11.642 & $\mathrm{C}_{11} \mathrm{H}_{14} \mathrm{O}_{4}$ & 209.0807 & 209.0814 & 193.0477; 175.0416 & 100 & -3.3 \\
\hline 17 & $p$-Coumaric acid ethyl ester & 12.672 & $\mathrm{C}_{11} \mathrm{H}_{12} \mathrm{O}_{3}$ & 191.0699 & 191.0708 & $\begin{array}{c}\text { 165.0252; 195.0582; } 119.0503 ; 116.9892 ; \\
\text { 179.0338; }\end{array}$ & 100 & -4.7 \\
\hline 18 & Trihydroxy octadecenoic acid isomer a & 14.400 & $\mathrm{C}_{18} \mathrm{H}_{34} \mathrm{O}_{5}$ & 329.2334 & 329.2328 & $229.1451 ; 211.1347 ; 171.1032 ; 183.1397$ & 99.8 & 1.8 \\
\hline 19 & Trihydroxy octadecenoic acid isomer b & 14.550 & $\mathrm{C}_{18} \mathrm{H}_{34} \mathrm{O}_{5}$ & 329.2332 & 329.2328 & $229.1451 ; 211.1347 ; 171.1032 ; 183.1397$ & 95.3 & 1.2 \\
\hline 20 & Trihydroxy octadecenoic acid isomer c & 15.295 & $\mathrm{C}_{18} \mathrm{H}_{34} \mathrm{O}_{5}$ & 329.2325 & 329.2328 & $229.1451 ; 211.1347 ; 171.1032 ; 183.1397$ & 99.6 & -0.9 \\
\hline 21 & Cyanidin & 15.853 & $\mathrm{C}_{15} \mathrm{H}_{11} \mathrm{O}_{6}$ & 286.2408 & 286.2400 & $265.0123 ; 116.1101$ & 92.3 & 0.7 \\
\hline 22 & Benzoic acid & 16.131 & $\mathrm{C}_{19} \mathrm{H}_{20} \mathrm{O}_{7}$ & 359.1118 & 359.1131 & $311.1693 ; 183.0196 ; 163.0394 ; 149.0360$ & 98.4 & -3.6 \\
\hline 23 & Dihydroxyoleic acid acid isomer a & 16.487 & $\mathrm{C}_{18} \mathrm{H}_{34} \mathrm{O}_{4}$ & 313.237 & 313.2379 & $183.1375 ; 295.2259 ; 269.0670$ & 100 & -2.9 \\
\hline 24 & Dihydroxyoleic acid isomer b & 16.570 & $\mathrm{C}_{18} \mathrm{H}_{34} \mathrm{O}_{4}$ & 313.2374 & 313.2379 & $201.1127 ; 223.0940 ; 171.1013$ & 100 & -1.6 \\
\hline 25 & Dihydroxyoleic acid isomer c & 16.830 & $\mathrm{C}_{18} \mathrm{H}_{34} \mathrm{O}_{4}$ & 313.2367 & 313.2379 & $171.1015 ; 277.2166 ; 295.2282$ & 100 & -3.8 \\
\hline 26 & Dihydroxyoleic acid isomer $\mathrm{d}$ & 16.917 & $\mathrm{C}_{18} \mathrm{H}_{34} \mathrm{O}_{4}$ & 313.2376 & 313.2379 & $157.0854 ; 171.1016 ; 187.0971$ & 100 & -1.0 \\
\hline 27 & Dihydroxystearic acid & 16.975 & $\mathrm{C}_{18} \mathrm{H}_{36} \mathrm{O}_{4}$ & 315.2531 & 315.2535 & $297.2422 ; 279.2317$ & 100 & -1.3 \\
\hline 28 & Hydroxylinoleic acid isomer a & 17.091 & $\mathrm{C}_{18} \mathrm{H}_{32} \mathrm{O}_{3}$ & 295.2263 & 295.2273 & $277.2172 ; 187.0946 ; 171.1006$ & 100 & -3.4 \\
\hline 29 & Hydroxypalmitic acid & 17.120 & $\mathrm{C}_{16} \mathrm{H}_{32} \mathrm{O}_{3}$ & 271.2262 & 271.2273 & $187.0974 ; 152.9931 ; 125.0954$ & 100 & -4.1 \\
\hline 30 & Hydroxylinoleic acid isomer $b$ & 17.202 & $\mathrm{C}_{18} \mathrm{H}_{32} \mathrm{O}_{3}$ & 295.2266 & 295.2273 & $277.2162 ; 171.1014 ; 195.1375$ & 100 & -2.4 \\
\hline 31 & Hydroxyoleic acid isomer a & 17.302 & $\mathrm{C}_{18} \mathrm{H}_{34} \mathrm{O}_{3}$ & 297.2418 & 297.2430 & 279.2306 & 100 & -4.0 \\
\hline 32 & Hydroxyoleic acid isomer b & 17.339 & $\mathrm{C}_{18} \mathrm{H}_{34} \mathrm{O}_{3}$ & 297.2418 & 297.2430 & 279.2319 & 100 & -4.0 \\
\hline
\end{tabular}


Table 3. Cont.

\begin{tabular}{|c|c|c|c|c|c|c|c|c|}
\hline No. & Compound & $\begin{array}{l}\text { Retention Time } \\
\text { (min) }\end{array}$ & $\begin{array}{l}\text { Molecular } \\
\text { Formula }\end{array}$ & $\begin{array}{c}m / z \\
\text { Experimental }\end{array}$ & $\begin{array}{c}m / z \\
\text { Calculated }\end{array}$ & Fragments & $\begin{array}{c}\text { Score } \\
(\%)\end{array}$ & $\begin{array}{l}\text { Error } \\
(\mathrm{ppm})\end{array}$ \\
\hline 33 & Hydroxyoleic acid isomer c & 17.384 & $\mathrm{C}_{18} \mathrm{H}_{34} \mathrm{O}_{3}$ & 297.2421 & 297.2430 & 279.2316 & 100 & -3.0 \\
\hline 34 & Hydroxylinoleic acid isomer c & 17.442 & $\mathrm{C}_{18} \mathrm{H}_{32} \mathrm{O}_{3}$ & 295.2263 & 295.2273 & $277.2166 ; 171.1017$ & 100 & -3.4 \\
\hline 35 & Hydroxystearic acid & 17.538 & $\mathrm{C}_{18} \mathrm{H}_{36} \mathrm{O}_{3}$ & 299.2575 & 299.2586 & $281.2489 ; 253.2527$ & 96.7 & -3.7 \\
\hline 37 & Linolenic acid & 17.753 & $\mathrm{C}_{18} \mathrm{H}_{30} \mathrm{O}_{2}$ & 277.2156 & 277.2168 & $279.2310 ; 255.2310$ & 100 & -4.3 \\
\hline 38 & Myristic acid & 17.782 & $\mathrm{C}_{14} \mathrm{H}_{28} \mathrm{O}_{2}$ & 227.2001 & 227.2011 & $152.9942 ; 209.0703$ & 100 & -4.4 \\
\hline 39 & Palmitoleic acid & 17.865 & $\mathrm{C}_{16} \mathrm{H}_{30} \mathrm{O}_{2}$ & 253.2161 & 253.2168 & 152.9945 & 100 & -2.8 \\
\hline 40 & Linoleic acid & 17.923 & $\mathrm{C}_{18} \mathrm{H}_{32} \mathrm{O}_{2}$ & 279.2319 & 279.2324 & $152.9952 ; 255.2314 ; 241.0059$ & 100 & -1.8 \\
\hline 41 & Methylpalmitic acid & 18.009 & $\mathrm{C}_{17} \mathrm{H}_{32} \mathrm{O}_{2}$ & 267.2319 & 267.2324 & $255.2336 ; 253.2151 ; 152.9937$ & 96.2 & -1.9 \\
\hline 43 & Oleic acid & 18.121 & $\mathrm{C}_{18} \mathrm{H}_{34} \mathrm{O}_{2}$ & 281.2472 & 281.2481 & $255.2308 ; 152.9945$ & 99.2 & -3.2 \\
\hline 44 & Heptadecanoic acid & 18.216 & $\mathrm{C}_{17} \mathrm{H}_{34} \mathrm{O}_{2}$ & 268.2473 & 268.2481 & $269.2477 ; 255.2326 ; 152.9957$ & 98.7 & -3.0 \\
\hline 45 & Stearic acid & 18.344 & $\mathrm{C}_{18} \mathrm{H}_{36} \mathrm{O}_{2}$ & 283.2629 & 283.2637 & $255.2336 ; 279.2322 ; 152.9945$ & 99.3 & -2.8 \\
\hline
\end{tabular}


At time 8.25 min (peak 8), the compound kaempferol 3,7-diglucoside has been identified according to its mass fragments 285 and 447. This compound could also be named sophoraflavonoloside or luteolin-7,3'-di-O-glucoside. Peak 1 had been previously detected but not quantified in fruits. It was named 2-O-galloyl-1,4-galactarolactone [20]. With the fragment $m / z 85$ corresponding with peak 5, L-leucic acid was tentatively identified. At time 1.16 (peak 3), with molecular formula $\mathrm{C}_{26} \mathrm{H}_{20} \mathrm{O}_{7}$ and the fragment with $m / z 229$, imbricantonol was found according to Byrne et al. (1987) [21], who found this compound for the first time in Stypandra glauca (blind grass). According to the authors, the fragments found for this compound indicate the possible couple of dianellidin $(\mathrm{m} / \mathrm{z} 215)$ with stypandrone $(m / z 229)$ and the presence of three hydroxyl substituents $(m / z 570)$. Peak 11 was identified as aspalathin (3-hydroxyphloretin 2'-O-glucoside), previously described as the major compound in Aspalathus linearis (rooibos) by Kreuz et al. (2008) [22]. At $m / z$ 683 (peak 14) and fragments at $m / z$ 721, 593 and 563, the veronicafolin 3-glucosyl-(1->3)galactoside has been tentatively identified according to Tan et al. (2020) [23] and previously described in Clinacanthus nutans, a popular herbal plant in the Southeast Asian region. Previously some studies have found flavonoids as kaempferol glycosides to have several roles in human health, including antioxidant, anti-inflammatory, antimicrobial, antidiabetic, anticancer, anti-osteoporotic, cardioprotective, anxiolytic, analgesic, and neuroprotective, among others [24].

Sinapyl alcohol and benzoic acid were identified at 11.64 and $16.13 \mathrm{~min}$, corresponding with peaks 16 and 22. Sinapyl alcogol has been described as a precursor to various stilbenes and coumarins, and benzoic acid as a precursor of phenolic acids [25].

The compounds with molecular formula $\mathrm{C}_{18} \mathrm{H}_{34} \mathrm{O}_{5}$ and fragments at $m / z 229,211$ and 171 (peaks 18, 19 and 20) were identified as trihydroxy octadecenoic acid isomers. They also could be named pinellic acid isomers, according to Ruan et al. (2019), who described them in Pluchea indica aerial parts [26]. Peaks 37-40 and 42-45 were identified as fatty acids, linolenic, myristic, palmitoleic, linoleic, palmitic, oleic, heptadecanoic, and stearic, according to several authors that found them in tiger nut oil [27-29]. Hydroxyoleic acid isomers (peaks 31-33, 35) and dihydroxyoleic acids isomers (peaks 23-26), derived from oleic acid, have also been found. Other derivates were found at different times: Hydroxystearic and dihydroxystearic acids at 17.54 and $16.98 \mathrm{~min}$, hydroxylinoleic acid isomers at 17.09, 17.20, and $17.44 \mathrm{~min}$, and hydroxypalmitic and methylpalmitic acids at 17.12 and $18.00 \mathrm{~min}$. Another fatty acid tentatively identified was trihydroxy octadecenoic acid isomers at peaks 18-20. None of which were previously described in tiger nut by-products.

\subsection{Quantification of Phenolic Compounds by HPLC-ESI-TOF-MS and Antioxidant Activity}

A total of 18 phenolic compounds were quantified, and they are summarized in Table 4.

Comparing the phenolic compounds (Table 4) in both tiger nut by-products, the PDO sample clearly has a higher amount of 2-O-galloyl-1,4-galactarolactone, scopoletin, imbricantonol, p-hydroxybenzoic acid, vanillic acid, ethyl vanillin, 4-vinylphenol, ferulic acid, $p$-coumaric acid, and p-coumaric acid ethyl ester. On the other hand, n-PDO byproduct is sightly richer in cyanidin, veronicafolin 3-glucosyl-(1->3)-galactoside, and the two phenolic compounds precursors, benzoic acid and sinapyl alcohol. Similar amounts of 3-hydroxyphloretin 2'-O-glucoside (aspalathin), kaempferol 3,7-diglucoside, and sinensetin were found in both samples.

The phenolic composition, mainly based on phenolic acids, justified the optimal conditions of extraction obtained in this work. In fact, according to Waszkowiak and Gliszczynska-Swigło, the phenolic acid content decreases when ethanol concentration is higher than 60 to $70 \%$ [30]. Similar data were reported by Roselló-Soto et al. [9], obtaining the highest recovery of phenolic acids in tiger nuts using $41.4 \%$ ethanol.

Compared with other authors, we have achieved a higher amount of cyanidin, 4vinylphenol, ethyl vanillin, and p-coumaric acid than Roselló-Soto et al. [9]. This could be because they used a conventional extraction while we used ultrasound bath assisted extraction; however, the difference between the samples must also be considered. No other 
references were found in the bibliography regarding phenolic compounds in tiger nut by-products.

Table 4. Phenolic compounds and their precursors quantified in PDO and n-PDO tiger nut by-product expressed as mean \pm standard deviation ( $\mu \mathrm{g} / \mathrm{g}$ dry weight (d.w.)).

\begin{tabular}{|c|c|c|c|}
\hline No. & Compound & PDO by-Product ( $\mu \mathrm{g} / \mathrm{g}$ d.w.) & n-PDO by-Product ( $\mu$ g/g d.w.) \\
\hline 1 & 2-O-Galloyl-1,4-galactarolactone & $29.17 \pm 2.55^{b}$ & $5.00 \pm 0.28^{\mathrm{a}}$ \\
\hline 2 & Scopoletin & $3.58 \pm 0.05^{b}$ & $1.44 \pm 0.03^{\mathrm{a}}$ \\
\hline 3 & Imbricantonol & $0.63 \pm 0.04^{b}$ & $<\mathrm{LOQ}^{\mathrm{a}}$ \\
\hline 4 & $p$-hydroxybenzoic acid & $0.62 \pm 0.03^{b}$ & $<\mathrm{LOQ}^{\mathrm{a}}$ \\
\hline 5 & Vanillic acid & $1.26 \pm 0.01^{b}$ & $0.97 \pm 0.02^{\mathrm{a}}$ \\
\hline 6 & Ethyl vanillin & $5.60 \pm 0.13^{b}$ & $0.55 \pm 0.01^{\mathrm{a}}$ \\
\hline 7 & 4-vinylphenol & $3.73 \pm 0.00^{b}$ & $0.88 \pm 0.02^{\mathrm{a}}$ \\
\hline 8 & Ferulic acid & $1.84 \pm 0.02^{b}$ & $1.19 \pm 0.06^{\mathrm{a}}$ \\
\hline 9 & $p$-coumaric acid & $0.77 \pm 0.15^{b}$ & $0.16 \pm 0.08^{\mathrm{a}}$ \\
\hline 10 & 3-Hydroxyphloretin 2'-O-glucoside (aspalathin) & $0.19 \pm 0.03^{\mathrm{a}}$ & $0.18 \pm 0.00^{\mathrm{a}}$ \\
\hline 11 & $\begin{array}{c}\text { Kaempferol 3,7-diglucoside, } \\
\text { sophoraflavonoloside or } \\
\text { luteolin-7,3'-di-O-glucoside }\end{array}$ & $0.14 \pm 0.01^{\mathrm{a}}$ & $0.10 \pm 0.02^{\mathrm{a}}$ \\
\hline 12 & Dehydrodivanillin & $2.27 \pm 0.04^{b}$ & $0.38 \pm 0.07^{\mathrm{a}}$ \\
\hline 13 & Veronicafolin 3-glucosyl-(1->3)-galactoside & $0.23 \pm 0.00^{\mathrm{a}}$ & $0.31 \pm 0.01^{b}$ \\
\hline 14 & Sinensetin & $0.03 \pm 0.00^{\mathrm{a}}$ & $0.03 \pm 0.00^{\mathrm{a}}$ \\
\hline 15 & Sinapyl alcohol & $1.37 \pm 0.41^{\mathrm{a}}$ & $2.49 \pm 0.58^{\mathrm{a}}$ \\
\hline 16 & $p$-Coumaric acid ethyl ester & $0.60 \pm 0.19^{\mathrm{a}}$ & $<\mathrm{LOQ}^{\mathrm{a}}$ \\
\hline 17 & Cyanidin & $0.67 \pm 0.09^{\mathrm{a}}$ & $1.01 \pm \hat{0.03} \mathrm{a}$ \\
\hline \multirow[t]{2}{*}{18} & Benzoic acid & $1.37 \pm 0.58^{\mathrm{a}}$ & $2.47 \pm 0.02^{\mathrm{a}}$ \\
\hline & Sum of phenolic compounds & $54.07 \pm 4.33^{\mathrm{b}}$ & $17.16 \pm 1.23^{\mathrm{a}}$ \\
\hline
\end{tabular}

Different letters $(a, b)$ in the same line indicate significant differences $(p<0.05)$.

In addition, $\mathrm{PDO}$ and n-PDO tiger nut by-products were revealed to have antioxidant activity (Table 5), being around 15\% higher for the PDO by-products with the three performed methods. Antioxidant activity has been reported previously in tiger nut oils [31] and tiger nut beverages [32]. However, no references were found in tiger nut by-products apart from those reported by Roselló-Soto et al. (2019) [9], but the method used was different (total antioxidant capacity).

Table 5. Antioxidant activity of PDO and n-PDO tiger nut by-product expressed as mean \pm standard deviation ( $\mu$ g Trolox equivalent (TE)/g dry weight (d.w.)).

\begin{tabular}{ccc}
\hline Antioxidant Assay & $\begin{array}{c}\text { PDO by-Product } \\
(\mu \mathbf{g} / \mathbf{g} \text { d.w. })\end{array}$ & $\begin{array}{c}\text { n-PDO by-Product } \\
(\mu \mathbf{g} / \mathbf{g} \text { d.w. })\end{array}$ \\
\hline DPPH & $434.41 \pm 4.73^{\mathrm{b}}$ & $356.90 \pm 5.56^{\mathrm{a}}$ \\
ABTS & $834.61 \pm 9.62^{\mathrm{b}}$ & $726.22 \pm 7.27^{\mathrm{a}}$ \\
FRAP & $757.48 \pm 6.55^{\mathrm{b}}$ & $618.31 \pm 7.89^{\mathrm{a}}$ \\
\hline
\end{tabular}

Different letters $(a, b)$ in the same line indicate significant differences $(p<0.05)$.

Roselló-Soto et al. (2018) [33] reported a total of 30 phenolic compounds that were previously found and quantified in tiger nut tubers. Parts of these phenols naturally remian in the horchata after the pressing steps; therefore, in the by-product, fewer compounds remain and in lower amounts. This corroborates the results obtained in this work as 18 phenolic compounds were identified and quantified in tiger nut industrial by-products. Besides, tiger nut by-products have a lower amount of phenolic compounds with lower antioxidant activity than tiger nut oils [31,34] and tiger nut by-product oils [10]. This is mainly because of the oil extraction techniques that hydrolysate the compounds. However, the use of ultrasound technology seems to be a promising technique to apply to tiger nut by-products that allow obtaining phenolic compounds with antioxidant activity. This 
makes it clear that the PDO tiger nut by-product contains higher amounts of phenolic compounds than the n-PDO tiger nut by-product. This result was realized as tiger nuts cultivated in Valencia (Spain) contain higher amounts of these antioxidants compared to the samples from Ivory Coast that contain more precursors. This difference could be justified with the growth differentiation balance framework. According to this hypothesis, when there are high levels of nitrogen and good environmental conditions, the growth of the plant is favored. On the contrary, if the environmental conditions are not favorable and the availability of essential components is low, the secondary metabolism is favored increasing the phenolic content. However, to confirm this trend, further analyses on the most robust sampling are needed.

\section{Conclusions}

The ultrasound-assisted extraction of phenolic compounds from tiger nut by-products has been established using a Box-Behnken design combined with RSM. The optimal selected conditions were $50 \mathrm{~min}, 40 \%$ ethanol, and ratio solvent/sample $80 \mathrm{v} / \mathrm{w}$. The results highlighted that ultrasound technology permits a high recovery of polyphenols from tiger nut by-product. Moreover, PDO and n-PDO tiger nut by-products were compared for the first time according to their phenolic composition and antioxidant activity. Both were characterized by HPLC-MS, and a total of 45 free polar compounds were identified, from which 27 polar compounds were identified for the first time in tiger nut by-products. The predominant compounds were phenolic acids, the major ones being 2-O-galloyl-1,4galactarolactone and vanillic acid derivatives. The quality attributed to the Protected Designation of Origin of Valencia has been confirmed in the PDO tiger nut by-product as it showed higher amounts of phenolic acids and other polyphenols also exhibiting higher antioxidant activity than the n-PDO tiger nut by-product. Further research, with a more robust sampling, could confirm the added value of Protected Designation of Origin of Valencia tiger nut by-products compared to n-PDO options.

To conclude, taking into account that the use of tiger nut flour for gluten-free products was studied, tiger nut by-products could be used as cheaper ingredients/flours for the formulation of bakery products.

Author Contributions: Conceptualization, E.J.G.-H. and V.V.; formal analysis, M.d.C.R.-D.; investigation, M.d.C.R.-D.; data curation, V.V., B.G.-V. and A.M.G.-C.; writing-original draft preparation, M.d.C.R.-D.; writing—review and editing, V.V. and A.M.G.-C.; supervision, E.J.G.-H. and V.V.; funding acquisition, V.V. and A.M.G.-C. All authors have read and agreed to the published version of the manuscript.

Funding: This research received no external funding.

Informed Consent Statement: Not applicable.

Data Availability Statement: Not applicable.

Acknowledgments: Vito Verardo thanks the Spanish Ministry of Economy and Competitiveness (MINECO) for "Ramon y Cajal" contract (RYC-2015-18795). The authors would like to thank the Puleva company for providing "horchata" by-products.

Conflicts of Interest: The authors declare no conflict of interest.

\section{References}

1. Sánchez-Zapata, E.; Fernández-López, J.; Pérez-Alvarez, J.Á. Tiger Nut (Cyperus esculentus) commercialization: Health aspects, composition, properties, and food applications. Compr. Rev. Food Sci. Food Saf. 2012, 11, 366-377. [CrossRef]

2. Sánchez-Zapata, E.; Fernández-López, J.; Pérez-Alvarez, J.A.; Soares, J.; Sousa, S.; Gomes, A.M.P.; Pintado, M.M.E. In vitro evaluation of "horchata" co-products as carbon source for probiotic bacteria growth. Food Bioprod. Process. 2013, 91, 279-286. [CrossRef]

3. Razola-Díaz, M.d.C.; Verardo, V.; Martín-García, B.; Díaz-De-Cerio, E.; García-Villanova, B.; Guerra-Hernández, E.J. Establishment of acid hydrolysis by box-behnken methodology as pretreatment to obtain reducing sugars from tiger nut byproducts. Agronomy 2020, 10, 477. [CrossRef] 
4. Sánchez-Zapata, E.; Muñoz, C.M.; Fuentes, E.; Fernández-López, J.; Sendra, E.; Sayas, E.; Navarro, C.; Pérez-Alvarez, J.A. Effect of tiger nut fibre on quality characteristics of pork burger. Meat Sci. 2010, 85, 70-76. [CrossRef] [PubMed]

5. Bobreneva, I.V.; Baioumy, A.A. Effect of using tiger nuts (Cyperus esculentus) on nutritional and organoleptic characteristics of beef burger. Biosci. Res. 2018, 15, 1424-1432.

6. Sánchez-Zapata, E.; Zunino, V.; Pérez-Alvarez, J.A.; Fernández-López, J. Effect of tiger nut fibre addition on the quality and safety of a dry-cured pork sausage ("Chorizo") during the dry-curing process. Meat Sci. 2013, 95, 562-568. [CrossRef] [PubMed]

7. Ezeh, O.; Niranjan, K.; Gordon, M.H. Effect of enzyme pre-treatments on bioactive compounds in extracted tiger nut oil and sugars in residual meals. J. Am. Oil Chem. Soc. 2016, 93, 1541-1549. [CrossRef]

8. Roselló-Soto, E.; Barba, F.J.; Putnik, P.; Kovačević, D.B.; Lorenzo, J.M.; Cantavella-Ferrero, Y. Enhancing bioactive antioxidants' extraction from "horchata de chufa" by-products. Foods 2018, 7, 161. [CrossRef]

9. Roselló-Soto, E.; Martí-Quijal, F.J.; Cilla, A.; Munekata, P.E.S.; Lorenzo, J.M.; Remize, F.; Barba, F.J. Influence of temperature, solvent and $\mathrm{pH}$ on the selective extraction of phenolic compounds from tiger nuts by-products: Triple-TOF-LC-MS-MS characterization. Molecules 2019, 24, 797. [CrossRef]

10. Roselló-Soto, E.; Barba, F.J.; Lorenzo, J.M.; Munekata, P.E.S.; Gómez, B.; Moltó, J.C. Phenolic profile of oils obtained from "horchata" by-products assisted by supercritical- $\mathrm{CO}_{2}$ and its relationship with antioxidant and lipid oxidation parameters: Triple TOF-LC-MS-MS characterization. Food Chem. 2019, 274, 865-871. [CrossRef]

11. Clemente-Villalba, J.; Cano-Lamadrid, M.; Issa-Issa, H.; Hurtado, P.; Hernández, F.; Carbonell-Barrachina, Á.A.; López-Lluch, D. Comparison on sensory profile, volatile composition and consumer's acceptance for PDO or non-PDO tigernut (Cyperus esculentus L.) milk. LWT 2021, 140, 110606. [CrossRef]

12. Singleton, V.L.; Orthofer, R.; Lamuela-Raventós, R.M. Analysis of Total Phenols and other oxidation substrates and antioxidants by means of Folin-Ciocalteu Reagent. In Oxidants and Antioxidants Part A, Methods in Enzymology; Accademic Press: Boston, MA, USA, 1999; Volume 299, pp. 152-178.

13. Verni, M.; Pontonio, E.; Krona, A.; Jacob, S.; Pinto, D.; Rinaldi, F.; Verardo, V.; Díaz-de-Cerio, E.; Coda, R.; Rizzello, C.G. Bioprocessing of brewers' spent grain enhances its antioxidant activity: Characterization of phenolic compounds and bioactive peptides. Front. Microbiol. 2020, 11, 1-15. [CrossRef] [PubMed]

14. Re, R.; Pellegrini, N.; Proteggente, A.; Pannala, A.; Yang, M.; Rice-Evans, C. Antioxidant activity applying an improved ABTS radical cation decolorization assay. Free Radic. Biol. Med. 1999, 26, 1231-1237. [CrossRef]

15. Brand-Williams, W.; Cuvelier, M.E.; Berset, C. Use of a free redical method to evaluate antioxidant activity. LWT-Food Sci. Technol. 1995, 28, 25-30. [CrossRef]

16. Parejo, I.; Codina, C.; Petrakis, C.; Kefalas, P. Evaluation of scavenging activity assessed by Co(II)/EDTA-induced luminol chemiluminescence and DPPH· (2,2-diphenyl-1-picrylhydrazyl) free radical assay. J. Pharmacol. Toxicol. Methods 2000, 44, 507-512. [CrossRef]

17. Pulido, R.; Bravo, L.; Saura-Calixto, F. Antioxidant activity of dietary polyphenols as determined by a modified ferric reducing/antioxidant power assay. J. Agric. Food Chem. 2000, 48, 3396-3402. [CrossRef]

18. Bezerra, M.A.; Santelli, R.E.; Oliveira, E.P.; Villar, L.S.; Escaleira, L.A. Response surface methodology (RSM) as a tool for optimization in analytical chemistry. Talanta 2008, 76, 965-977. [CrossRef]

19. Pei, K.; Ou, J.; Huang, J.; Ou, S. p-Coumaric acid and its conjugates: Dietary sources, pharmacokinetic properties and biological activities. J. Sci. Food Agric. 2016, 96, 2952-2962. [CrossRef]

20. Yannai, S. Dictionary of Food Compounds with CD-ROM: Additives, Flavors, and Ingredients; Chapman \& Hall/CRC: Boca Raton, FL, USA, 2004.

21. Byrne, L.T.; Colegate, M.S.; Darling, P.R.; Huxtable, C.R. Imbricatonol, a naphthol-naphthoquinone dimer isolated from stypandra imbricata and dianella revoluta. Aust. J. Chem. 1987, 40, 1315-1320. [CrossRef]

22. Kreuz, S.; Joubert, E.; Waldmann, K.H.; Ternes, W. Aspalathin, a flavonoid in Aspalathus linearis (rooibos), is absorbed by pig intestine as a C-glycoside. Nutr. Res. 2008, 28, 690-701. [CrossRef]

23. Tan, H.M.; Leong, K.H.; Song, J.; Mohd Sufian, N.S.F.; Mohd Hazli, U.H.A.; Chew, L.Y.; Kong, K.W. Antioxidant and LC-QToFMS/MS analysis of polyphenols in polar and non-polar extracts from Strobilanthes crispus and Clinacanthus nutans. Int. Food Res. J. 2020, 27, 903-914.

24. Calderón-Montaño, J.M.; Burgos-Morón, E.; Pérez-Guerrero, C.; López-Lázaro, M. A review on the dietary flavonoid kaempferol I BenthamScience. Mini Rev. Med. Chem. 2011, 11, 298-344. [CrossRef] [PubMed]

25. Boerjan, W.; Ralph, J.; Baucher, M. Lignin Biosynthesis. Annu. Rev. Plant Biol. 2003, 54, 519-546. [CrossRef] [PubMed]

26. Ruan, J.; Yan, J.; Zheng, D.; Sun, F.; Wang, J.; Han, L.; Zhang, Y.; Wang, T. Comprehensive chemical profiling in the ethanol extract of Pluchea indica aerial parts by liquid chromatography/mass spectrometry analysis of its silica gel column chromatography fractions. Molecules 2019, 24, 2784. [CrossRef] [PubMed]

27. Duman, E. Some physico-chemical properties, fatty acid compositions, macro-micro minerals and sterol contents of two variety tigernut tubers and oils harvested from east mediterranean region. Food Sci. Technol. 2019, 39, 610-615. [CrossRef]

28. Aljuhaimi, F.; Ghafoor, K.; Özcan, M.M.; Miseckaite, O.; Babiker, E.E.; Hussain, S. The effect of solvent type and roasting processes on physico-chemical properties of tigernut (Cyperus esculentus L.) tuber oil. J. Oleo Sci. 2018, 67, 823-828. [CrossRef] 
29. Roselló-Soto, E.; Barba, F.J.; Lorenzo, J.M.; Dominguez, R.; Pateiro, M.; Mañes, J.; Moltó, J.C. Evaluating the impact of supercritical$\mathrm{CO}_{2}$ pressure on the recovery and quality of oil from "horchata" by-products: Fatty acid profile, $\alpha$-tocopherol, phenolic compounds, and lipid oxidation parameters. Food Res. Int. 2019, 120, 888-894. [CrossRef]

30. Waszkowiak, K.; Gliszczynska-Swigło, A. Binary ethanol-water solvents affect phenolic profile and antioxidant capacity of flaxseed extracts. Eur. Food Res. Technol. 2016, 242, 777-786. [CrossRef]

31. Guo, T.; Wan, C.; Huang, F.; Wei, C. Evaluation of quality properties and antioxidant activities of tiger nut (Cyperus esculentus L.) oil produced by mechanical expression or/with critical fluid extraction. LWT 2021, 141, 110915. [CrossRef]

32. Badejo, A.A.; Olawoyin, B.; Salawu, S.O.; Fasuhanmi, O.S.; Boligon, A.A.; Enujiugha, V.N. Antioxidative potentials and chromatographic analysis of beverages from blends of gluten-free acha (Digitaria exilis) and tigernut (Cyperus esculentus) extracts. J. Food Meas. Charact. 2017, 11, 2094-2101. [CrossRef]

33. Roselló-Soto, E.; Poojary, M.M.; Barba, F.J.; Lorenzo, J.M.; Mañes, J.; Moltó, J.C. Tiger nut and its by-products valorization: From extraction of oil and valuable compounds to development of new healthy products. Innov. Food Sci. Emerg. Technol. 2018, 45, 306-312. [CrossRef]

34. Koubaa, M.; Barba, F.J.; Mhemdi, H.; Grimi, N.; Koubaa, W.; Vorobiev, E. Gas assisted mechanical expression (GAME) as a promising technology for oil and phenolic compound recovery from tiger nuts. Innov. Food Sci. Emerg. Technol. 2015, 32, 172-180. [CrossRef] 